\section{Goodbye to guidelines}

\section{Recombinant DNA guidelines are on the way out. What should be learned from them?}

This week's meeting of the Recombinant DNA Advisory Committee at the National Institutes of Health in the United States will be seen as not so much a landmark as a milestone in the brief but eventful history of the most elaborate attempt so far to regulate scientific research. After two years of agonizing in the wake of the Asilomar conference of 1974, government agencies produced rules for research with recombinant DNA which, once promulgated, were almost as quickly dismantled. Already, the guidelines in force are a pale shadow of the tough regulations that caused many professional people to protest that governments were planning to interfere with research - and many members of the lay public to complain that the controls were entirely inadequate. But on present form, the whole apparatus of regulation will have all but disappeared within a decade of being proposed. Has the whole exercise been a waste of busy people's time? What can be learned from it?

That busy people's time has been occupied is of course beyond dispute. People who might have been cloning some gene, or setting up some new biotechnology company, have instead been required to turn up at meetings of advisory and safety committees. There is probably also something in the complaint that important experiments were delayed by the lack of facilities necessary for compliance with the guidelines, or by the diversion of creative people's talents to the development of organisms even less capable of survival in the human gut than the standard laboratory strains of $E$. coli $\mathrm{K} 12$. So, now, there are two commonplace appraisals of the experience of the past few years. Some workers in the field claim that they have said from the beginning that the potential dangers of recombinant DNA research were exaggerated, and that the regulations were pointless and a needless interference with free research. Others, more circumspect but also more cynical, say that the guidelines were an unfortunate necessity, an exercise in public relations whose value is attested by the way in which the public clamour about the hazards of genetic manipulation has died down. The truth, however, lies with the smaller company of professionals who acknowledge that the guidelines were both necessary and valuable, that experience of their operation has been instructive and that the history of the recent past should be remembered well.

The argument is simple and straightforward. At Asilomar and in the months that followed, many people in a good position to know the truth held that the hazards for the general population of the construction of novel organisms could be serious. The hazards were always hypothetical, involving processes not then (or since) demonstrated in the real world. Those who claim to have known all along that the guidelines were unnecessary did at the time argue that organisms encumbered artificially with foreign genes were unlikely to be effective competitors in tissues which they happened to infect, but were too scornful of the now common difficulty of deciding how to assess a large danger which has only a very small probability. In the event, the erosion of the guidelines promulgated by the National Institutes of Health (and analogues elsewhere) has been made possible by scientific rather than philosophical developments - the discovery that the replication of genes in eukaryotic cells is more complicated than in bacteria for example. In 1976, the decision that there should be guidelines of some sort was not merely prudent but responsible. So, now, is the general agreement that the guidelines may be further attenuated without risk.

For the most part, the guidelines have also been well kept, even by the sceptics. The few know transgressions, in the United States and elsewhere, appear to have been engendered as much by frustration at the differences in guidelines applying to competing laboratories as to deliberate attempts at cheating. In the United States, the dominant role of the National Institutes of Health in supporting research must have been a powerful deterrent - which is why, in the history of this period, the failure of successive Administrations to apply to industrial laboratories the sanctions applicable to academic laboratories will seem odd, to say the least. Where guidelines have been backed by legislation, as in the United Kingdom, the courts have not been packed with recalcitrant molecular biologists. The scientific community can claim credit on this score.

So what should happen now? Should the guidelines simply be torn up, and the accompanying bureaucratic apparatus dismantled? That would be to go too far. To the extent that the foreseeable hazards of recombinant DNA research have become no more than coextensive with the risks of working with whatever naturally occurring organisms are involved, the existing rules for research with pathogenic organisms are sufficient. Separate rules for recombinant DNA research are therefore unnecessary, while voluntary compliance with further attenuated regulations will be meaningless. Yet the issues which have been raised in the past several years are interesting and have also made a mark on the public mind. What is needed, now, is a periodic and public reassessment of the risks, hypothetical though they may still be.

For laboratories, the most important procedural discovery since Asilomar is that local safety committees have not turned out to be the interfering busybodies they were feared to be. Even when (as required by the National Institutes of Health) lay members were appointed, the outcome has more often been public enlightenment than outside intrusion into the conduct of research. Indeed, the precedent of local safety committees including members from the nearby community is one that should be more widely adopted in other fields, for example where laboratories have an interest that they should be known to care for their experimental animals - and that the general public should be sensible of their dilemma. It would be no harm if this institution were the chief monument to the guidelines period.

\section{Maths without teachers}

\section{British schoolteachers cannot teach mathematics properly, but nobody is surprised.}

How should mathematics be taught? And by whom? These questions have perplexed the British educational system ever since it acknowledged, in the $1950 \mathrm{~s}$, that everybody profits from education, of which mathematics is an essential ingredient. In despair at not knowing how the questions should be answered, in September 1978, the then British government set up a committee under Dr W.H. Cockcroft, Vice-chancellor of the New University of Ulster in Coleraine, to suggest what might be done. The committee's report now published (Mathematics Counts, HMSO, £5.75) is as well polished as the time it has taken to prepare requires in decency that it should be. It is also full of sensible suggestions for the better organization of mathematics teaching in British schools. But on the main issues, the report is muffled.

The trouble with mathematics teaching is that the shortcomings of one part of the educational system are visited upon all others. University courses in mathematics, notoriously arid, are also the chief source of teachers in secondary schools who are saddled with responsibility for teaching mathematics to intending teachers in primary schools. Hitherto (and, indeed, until 1983) it has been possible for young people to embark on careers as teachers without having a formal qualification in mathematics at secondary school, even though they will be required to teach mathematics to young children. The result is that mathematics teaching is everywhere tentative - experts in graph theory teach elementary algebra to thirteen-year-olds, inexpert people wrestle with seven-year-olds on the conundrum of proportionality. The underlying fault, which Cockcroft does not tackle, is that the British educational system makes a fetish of specialization too early, and pays too little regard to general education at all levels. Paying some good mathematics teachers more, and the other stratagems he advocates, may help in the short run. Changing the way the British educate their young is the only long-term remedy. 